\title{
Review \\ Clinical review: Prevention and therapy of vasospasm in subarachnoid hemorrhage
}

\author{
Salah G Keyrouz and Michael N Diringer
}

Neurology/Neurosurgery Intensive Care Unit, Department of Neurology, Washington University School of Medicine, South Euclid Avenue, St Louis, MO 63110, USA

Corresponding author: Salah G Keyrouz, salahkeyrouz@hotmail.com

Published: 14 August 2007

This article is online at http://ccforum.com/content/11/4/220

Critical Care 2007, 11:220 (doi:10.1186/cc5958)

(c) 2007 BioMed Central Ltd

\begin{abstract}
Vasospasm is one of the leading causes of morbidity and mortality following aneurysmal subarachnoid hemorrhage (SAH). Radiographic vasospasm usually develops between 5 and 15 days after the initial hemorrhage, and is associated with clinically apparent delayed ischemic neurological deficits (DID) in one-third of patients. The pathophysiology of this reversible vasculopathy is not fully understood but appears to involve structural changes and biochemical alterations at the levels of the vascular endothelium and smooth muscle cells. Blood in the subarachnoid space is believed to trigger these changes. In addition, cerebral perfusion may be concurrently impaired by hypovolemia and impaired cerebral autoregulatory function. The combined effects of these processes can lead to reduction in cerebral blood flow so severe as to cause ischemia leading to infarction. Diagnosis is made by some combination of clinical, cerebral angiographic, and transcranial doppler ultrasonographic factors. Nimodipine, a calcium channel antagonist, is so far the only available therapy with proven benefit for reducing the impact of DID. Aggressive therapy combining hemodynamic augmentation, transluminal balloon angioplasty, and intra-arterial infusion of vasodilator drugs is, to varying degrees, usually implemented. A panoply of drugs, with different mechanisms of action, has been studied in $\mathrm{SAH}$ related vasospasm. Currently, the most promising are magnesium sulfate, 3-hydroxy-3-methyl-glutaryl-CoA reductase inhibitors, nitric oxide donors and endothelin-1 antagonists. This paper reviews established and emerging therapies for vasospasm.
\end{abstract}

\section{Introduction}

Vasospasm is a common complication that follows aneurysmal subarachnoid hemorrhage (SAH). Ecker was first to point out the occurrence of arterial spasm following SAH [1]. Before him, Robertson had attributed ischemic brain lesions found on autopsy of patients with SAH to probable 'spasm of arteries' [2]. Despite growing literature, skepticism regarding the association between angiographic vasospasm and clinical findings persisted [3], until CM Fisher and colleagues published a synopsis on the matter in 1977 [4]. This seminal publication comprehensively described the deficits accompanying vasospasm and, most importantly, made the association between vasospasm and neurological deficits, also known as delayed ischemic deficits (DID).

The term vasospasm implies a reduction in the caliber of a vessel; however, in $\mathrm{SAH}$ it has multiple meanings. $\mathrm{SAH}$ induced vasospasm is a complex entity due in part to a delayed and reversible vasculopathy, impaired autoregulatory function, and hypovolemia causing a regional reduction of cerebral perfusion to the point of causing ischemia $[5,6]$.

Radiographic evidence of vasospasm develops in 50\% to $70 \%$ of patients with $\mathrm{SAH}$, but only half of those experience symptoms of DID [7-12]. Proximal vessels, situated at the base of the brain, are preferentially affected; however, more distal arteries could also develop impaired vascular reactivity (autoregulation), further reducing cerebral blood flow $[5,13,14]$. A tendency toward spontaneous intravascular volume contraction can further compound the deleterious effect of a marginal cerebral blood flow (CBF) caused by vasoconstriction. These factors are probably in play in a subset of patients with DID who show no evidence of radiographic vasospasm.

Vasospasm adversely affects outcome in patients with $\mathrm{SAH}$; it accounts for up to $23 \%$ of disability and deaths related to $\mathrm{SAH}[8,9,15-17]$. However, given its predictable delayed onset between day 5 and 15 after bleeding, it is a potentially modifiable factor. Use of nimodipine, a calcium channel antagonist, and prompt recognition and treatment with hypervolemic hypertensive therapy (HHT) and endovascular interventions are likely responsible for the lower incidence of

$\mathrm{CBF}=$ cerebral blood flow $\mathrm{CSF}=$ cerebrospinal fluid $\mathrm{DID}=$ delayed ischemic deficits; $\mathrm{eNOS}=$ endothelial nitric oxide synthase; $\mathrm{ET}=$ endothelin; $\mathrm{HHT}=$ hypervolemic hypertensive therapy; $\mathrm{Mg}^{++}=$magnesium sulfate; $\mathrm{NO}=$ nitric oxide; $\mathrm{NOS}=$ nitric oxide synthase; $\mathrm{SAH}=$ subarachnoid hemorrhage; SPECT = single photon emission computed tomography; TBA = transluminal balloon angioplasty; TCD = transcranial doppler ultrasonography. 
DID reported after their widespread use $[17,18]$. They are by no means completely effective and additional treatments are needed. The ongoing elucidation of the pathophysiology of vasospasm is crucial, as it offers targets for novel therapeutic modalities.

\section{Pathophysiology}

The pathophysiology of vasospasm is far from being completely understood. Histologically, there are structural alterations in endothelial and smooth muscle cells in the arterial wall [19]. The presence of oxyhemoglobin in the subarachnoid space seems to be necessary to produce these changes [20-22]. The specific mechanisms leading to vasoconstriction, however, are unknown. In vitro, oxyhemoglobin stimulates the secretion of endothelin (ET)-1, a vasoconstrictor, inhibits the vasodilator nitric oxide (NO) and produces activated oxygen species [2325]. These free radicals are believed to play a role in cell membrane lipid peroxidation, possibly mediating the structural changes in the vessel wall.

Whether inflammation is simply part of the multi-organ system dysfunction encountered in SAH [26] or contributes to the development of vasospasm is unsettled. The risk of vasospasm is increased in the presence of systemic inflammatory response syndrome [27]. Furthermore, cerebrospinal fluid (CSF) levels of interleukin- $1 \beta$ and -6 in patients with SAH are increased during the vasospasm period and in those in whom vasospasm and ischemia develop later [28]. Genetic and racial factors are likely important; studies of SAH from Japan revealed a higher incidence of vasospasm across different diagnostic methods [29]. Also, certain endothelial NO synthase (eNOS) gene polymorphisms seem to be associated with an increased risk of vasospasm [30].

Risk factors for vasospasm and DID are amount and duration of exposure to subarachnoid blood, thick blood collections in basal cisterns and fissures, and intraventricular blood [31-34]. Interestingly, however, endovascular coiling of the ruptured aneurysm, a procedure that does not involve a craniotomy and washing out of the subarachnoid blood, does not increase the risk of vasospasm in comparison to surgical clipping [35,36]. Advanced age [37], race [29], poor neurological status on admission $[17,37,38]$ and use of antifibrinolytic agents $[16,33,39]$ are also associated with the development of DID. Factors less robustly linked to a higher incidence of DID are a longer duration of unconsciousness following the initial hemorrhage [40], history of hypertension $[37,41]$, smoking $[42,43]$, and excess weight [41].

\section{Diagnosis of vasospasm Clinical diagnosis}

The diagnosis of vasospasm is primarily clinical. Vasospasm can be asymptomatic; however, when the net result of vasoconstriction, impaired autoregulation, and inadequate intravascular volume is a CBF below ischemic threshold, symptoms ensue. They typically develop subacutely, and
Table 1

Detection of symptomatic vasospasm (mean flow velocity $>120 \mathrm{~cm} / \mathrm{s}$ ) by transcranial doppler ultrasonography compared to clinical examination

\begin{tabular}{lcccc}
\hline Vessel & Sensitivity & Specificity & $\begin{array}{c}\text { False } \\
\text { negative rate }\end{array}$ & $\begin{array}{c}\text { False } \\
\text { positive rate }\end{array}$ \\
\hline MCA & 64 & 78 & 36 & 22 \\
ICA & 80 & 77 & 20 & 23 \\
ACA & 45 & 84 & 55 & 16 \\
\hline
\end{tabular}

Values represent percentages with clinical diagnosis used as the standard method for diagnosing symptomatic vasospasm. Adapted from [49]. ACA, anterior cerebral artery; ICA, internal cerebral artery; MCA, middle cerebral artery.

because of the dynamic interplay between the inciting factors, they might fluctuate. Symptoms range from vague and non-specific, such as excess sleepiness, lethargy, and stupor, to a spectrum of localizing findings like hemiparesis or hemiplegia, abulia, language disturbances, visual fields deficits, gaze impairment, and cranial nerve palsies [4]. Although localizing, these signs are not diagnostic of any specific pathological process; therefore, alternative diagnoses, such as rebleeding, hydrocephalus, seizures and metabolic derangements, should be promptly excluded using radiographic, clinical and laboratory assessments. On the other hand, the neurological changes can be subtle or unapparent, as many individuals have an abnormal exam related to the initial hemorrhage. Detection of clinical signs of vasospasms is particularly difficult in poor grade patients because of the limited exam that is possible [44]. The frequent use of sedatives in SAH patients further complicates this task. Thus, the evaluation frequently includes transcranial doppler ultrasonography (TCD) and angiography. Angiography can be both diagnostic and therapeutic (see below).

\section{Cerebral angiography and transcranial doppler ultrasonography}

Cerebral angiography is the gold standard for visualizing and studying cerebral arteries. The non-invasive nature of TCD, however, makes it an appealing method for monitoring for, and to help confirm, the clinical diagnosis of vasospasm. It detects elevation in mean CBF velocities, mainly in middle and internal cerebral arteries $[45,46]$. Although it is almost as sensitive as angiography in detecting symptomatic vasospasm [47-49], inadequate insonation window in a proportion of patients, unacceptably high rate of false negatives [48], and failure to account for altered autoregulation during hemodynamic manipulation [13] limit its utility (Table 1).

\section{Emerging modalities}

The ability of other imaging modalities, like perfusion computed tomography [50,51], Xenon computed tomography [52,53], diffusion weighted magnetic resonance imaging [54,55], and single photon emission computed tomography (SPECT) 
$[51,56]$ in detecting vasospasm are under investigation. These imaging techniques could soon become routine in the diagnosis of vasospasm [57]. Unlike cerebral angiography and TCD, these techniques measure regional perfusion, not merely arterial diameter or flow velocities. Online microdialysis is another new technique currently being studied in vasospasm [58]. It involves measuring extracellular cerebral fluid levels of an array of substances like glucose, glutamate, lactate, and pyruvate.

\section{Reducing the impact of vasospasm}

The typical temporal course of vasospasm and its high incidence make prevention an attractive therapeutic approach. However, the process is a difficult one to study and despite investigation of a myriad of compounds, very few have made it to the clinical arena (Additional data file 1).

\section{Nimodipine}

Nimodipine is a dihydropyridine that blocks calcium influx through the L-type calcium channels. It is the most rigorously studied and only drug approved by the US Food and Drug Administration for use in treatment of vasospasm. It is safe [12,59], cost-effective [60], and most importantly reduces the risk of poor outcome and secondary ischemia after aneurysmal SAH [7,10-12,61]. A major randomized controlled trial, the British aneurysm oral nimodipine trial, showed a significant reduction in the incidence of cerebral infarction and poor outcome at three months compared to placebo [12].

How nimodipine exerts its beneficial effects is not well understood and may involve neuronal as well as vascular factors, although, of note, it does not significantly reverse angiographic vasospasm [62]. Nimodipine is administered in a dose of $60 \mathrm{mg}$ every 4 hours for 14-21 days after SAH. In Europe, nimodipine is also used as a continuous intravenous infusion, although this is often associated with hypotension.

\section{Other calcium channel antagonists}

Nicardipine [62-65] and diltiazem [62,63,66,67] have both been studied, but only nicardipine in a controlled fashion. In a large randomized trial nicardipine decreased the incidence of DID, reduced the use of HHT and reduced angiographic vasospasm, yet it did not improve overall outcome at 3 months $[62,64,65]$. An unblinded small study of prophylactic, serial intrathecal nicardipine was conducted in 50 patients with $\mathrm{SAH}$. This approach reduced the incidence of both angiographic and clinical vasospasm and improved good clinical outcome at 1 month by $15 \%$. Adverse events were frequent; nine patients developed headache and two had meningitis [68].

Phase I and II safety studies of diltiazem in SAH demonstrated safety but no effect on vasospasm [67]. A recently published paper describing a series of $123 \mathrm{SAH}$ patients treated with oral diltiazem instead of nimodipine reported a $19.5 \%$ incidence of DID [66]. Favorable outcome (Glasgow Outcome Scale of 4 or 5 ) was achieved in $75 \%$ of patients.

\section{Tirilazad mesylate}

Tirilazad, a non-glucocorticoid 21 amino-steroid free radical scavenger, was studied in several controlled trials [69-73] following promising results in primate vasospasm models [74-76]. It was well tolerated but had inconsistent effect on overall outcome across the different studies, possibly related to gender differences in drug metabolism and an interaction with phenytoin.

\section{Prophylactic hypervolemia}

In large prospective controlled studies, prophylactic volume expansion therapy failed to reduce the incidence of clinical or TCD-defined vasospasm, did not improve CBF, and had no effect on outcome [77-79]. In one of those studies, costs and complications were higher in the group treated with prophylactic hypervolemia [77]. A small retrospective cohort reported worsening outcome after discontinuing routine use of albumin to induce hypervolemia in $\mathrm{SAH}$ [80].

\section{Lumbar drainage of CSF and intracisternal thrombolysis}

The amount of blood in the subarachnoid space is a strong predictor for the development of vasospasm. Several interventions to facilitate the clearance of blood from the CSF following $\mathrm{SAH}$ have been studied. Cisternal irrigation by tissue plasminogen activator [81] was relatively safe [82,83] but had no impact on incidence of angiographic vasospasm [84]. Intraand post-operative cisternal irrigation with tissue plasminogen activator combined with continuous post-operative cisternal drainage was associated with a low incidence of vasospasm [85]. Intracisternal infusion of urokinase has also been studied in a small retrospective randomized, but not placebocontrolled trial [86,87]. Incidence of vasospasm was significantly reduced and outcome improved.

Lumbar CSF drainage following $\mathrm{SAH}$ is another appealing technique to clear blood from the subarachnoid space. A non-randomized, controlled-cohort study enrolled 167 patients in whom CSF drainage reduced the incidence of clinical vasospasm, the use of angioplasty, and vasospasmrelated infarction [88]. Larger placebo controlled studies are needed to determine if these interventions produce sustained clinical benefits.

\section{Prophylactic transluminal balloon angioplasty}

Following promising experimental results, a pilot study of prophylactic transluminal balloon angioplasty (TBA) was undertaken in a group of 13 patients with Fisher grade $3 \mathrm{SAH}$ [89]. None of the patients developed DID. Recently, a multi-center randomized trial evaluated the use of prophylactic TBA in a larger group of patients [90]. The procedure showed no benefit, and was responsible for 3 deaths (4\%) from vessel rupture, an incidence higher than the $1.1 \%$ reported in the literature [91].

\section{Aggressive treatment of vasospasm}

Given the limited impact of established and developing preventive measures, more aggressive interventions are often 
implemented. The threshold for instituting these interventions varies widely across centers. Some actively intervene in the setting of rising TCD velocities; others may treat angiographic vasospasm in asymptomatic patients, while some require a neurological deterioration before instituting aggressive measures. The ideal therapeutic combination would improve CBF, reverse or attenuate DID, and have low potential for adverse events. While this intervention has yet to be defined, varying combinations of medical and endovascular approaches are widely used to treat vasospasm.

\section{Medical therapy}

$\mathrm{HHT}$, also described as hemodynamic augmentation, is the cornerstone of medical therapy for vasospasm. The varying nomenclature reflects the fact that it is unclear which specific intervention is most effective. Studies of CBF in SAH patients undergoing HHT have yielded varying results. While acute volume expansion in patients with symptomatic vasospasm increased CBF in areas of brain most vulnerable to ischemia on positron emission tomography (PET) [92], prophylactic hypervolemia did not produce such a response when SPECT [77] or ${ }^{133} \mathrm{Xe}$ clearance [78] were used. HHT appears safe following endovascular coiling of aneurysm [93], and even in patients with prior cardiac disease [94].

In clinical practice, attempts to keep symptomatic patients hypervolemic using crystalloids or colloids should be made. Although exact criteria have been hard to establish, hypertension is induced using vasopressors until there is clinical improvement, a preset limit is reached, or adverse effects occur. Clinical improvement can be dramatic [94], but is an inconsistent finding across case series. Prospective controlled outcome studies of hemodynamic interventions are lacking. Yet, such clinical trials are unlikely to be completed given the widespread use of these interventions.

\section{Endovascular therapy}

Endovascular techniques frequently play a role in the aggressive treatment of vasospasm $[95,96]$. They include TBA and intra-arterial infusion of vasodilators. Both methods have their unique associated risks and benefits and are usually undertaken after a trial of medical therapy except in patients with severe cardiac disease.

\section{Transluminal balloon angioplasty}

TBA is very effective at reversing angiographic spasm of large proximal vessels. It produces a sustained reversal of arterial narrowing, although clinical improvement is inconsistent [97-99]. The timing of TBA in regard to medical therapy is controversial. Some retrospective data suggest that early angioplasty (within 2 hours from onset of symptoms) is associated with sustained clinical improvement [100].

Age and poor neurological status are associated with poor outcome following TBA for symptomatic vasospasm [101]. The sustained effect of angioplasty may well be due to its ability to disrupt connective tissue, as has been seen in the media of cerebral arteries removed at autopsy from patients who underwent the procedure [102]. Major complications of TBA are encountered in about $5 \%$ of procedures [91] and include vessel rupture, occlusion, dissection, hemorrhagic infarction and hemorrhage from unsecured aneurysms [96].

\section{Intra-arterial vasodilators}

Papaverine is a potent smooth muscle relaxant; its use in $\mathrm{SAH}$ related vasospasm has been extensively studied. It is infused intra-arterially through a micro-catheter proximal to the vasospastic vessel. In most cases, its effect on angiographic vasospasm is immediate and dramatic [103-106] but reversal of clinical deficits is variable [91]. Papaverine has been shown to transiently improve regional CBF $[103,107]$. The effect of papaverine on outcome is unknown. In one study, when compared to patients with similar characteristics and degree of vasospasm, patients who were treated with papaverine had similar outcome at three months [108].

In most centers, use of papaverine has been relegated to a secondary role or altogether abandoned because of its shortlived effect and a myriad of complications. The most serious are increased intracranial pressure [109], brainstem depression [110], worsening of vasospasm [111,112], neurological deterioration with gray matter changes on MRI [113], and seizures [114].

This has led to growing use of intra-arterial nicardipine, verapamil, nimodipine, and milrinone as alternatives to papaverine. Nicardipine reverses angiographic vasospasm and significantly reduces mean peak systolic velocities in treated vessels, with no sustained effect on intracranial pressure or cardiovascular function [115]. Verapamil is reported to reduce angiographic spasm and produce clinical improvement in a third of cases without significant adverse events [116]. Nimodipine showed similar favorable results in two small retrospective series $[117,118]$. Controlled clinical trials are lacking.

\section{Future directions}

A number of therapies are currently being developed and are at different stages of testing. They include magnesium sulfate $\left(\mathrm{Mg}^{++}\right)$, statins, NO donors, and ET-1 antagonists.

\section{Magnesium sulfate}

Hypomagnesemia on admission occurs in $38 \%$ of individuals with SAH [119]. Whether it independently predicts the development of DID is controversial $[119,120]$. The appeal of $\mathrm{Mg}^{++}$in SAH stems from its biochemical properties as a physiological antagonist of calcium [121], ease of administration, low cost, the ability to measure and regulate concentration in body fluids [122,123], and favorable safety profile.

There have been a number of encouraging reports on the effect of $\mathrm{Mg}^{++}$in animal models of $\mathrm{SAH}$ related vasospasm 
[124-127]. In patients with stroke and $\mathrm{SAH}$, administration of $\mathrm{Mg}^{++}$is practical and safe [122,123,128-131]. In a pilot, randomized, double blind study comparing $\mathrm{Mg}^{++}$to saline there was a trend toward less symptomatic vasospasm with $\mathrm{Mg}^{++}$[129]. Yet a large controlled trial of continuous $\mathrm{Mg}^{++}$ infusion did not find conclusive effects on DID or outcome [132]. In a small, single-center trial $\mathrm{Mg}^{++}$was similar to intravenous nimodipine in preventing DID [133]. On the other hand, $\mathrm{Mg}^{++}$was of no added benefit in patients receiving prophylactic hypervolemia/hemodilution [134]. Interestingly, a TCD study showed no improvement in elevated mean flow velocities in middle cerebral arteries of patients with clinical vasospasm after receiving a bolus infusion of $\mathrm{Mg}^{++}$[135].

\section{Statins}

Statins, or 3-hydroxy-3-methyl-glutaryl-CoA reductase inhibitors, appear to have a promising role in vasospasm prevention. The proposed mechanism of neuroprotection in vasospasm is related to induction of the NOS pathway, leading to dilation of cerebral vessels and improved CBF [136-138].

Two small randomized placebo-controlled, single-center studies investigated the safety and feasibility of statins in $\mathrm{SAH}$. In one study, pravastatin reduced the incidence of TCD-defined vasospasm and shortened the duration of severe vasospasm [139]. Another randomized controlled trial used simvastatin in a smaller group of patients [140]. The incidence of TCD-defined vasospasm and DID was significantly reduced in the simvastatin group. The routine use of statins in $\mathrm{SAH}$ is awaiting larger, multi-center clinical trials showing clear reduction in DID and improvement in overall outcome.

\section{Nitric oxide donors}

$\mathrm{NO}$ is a free radical gas formed by the enzyme NOS from the substrate L-arginine. It was discovered in 1987 [141] and appears to have a crucial role in controlling cerebral vasomotor tone. Tonic release of $\mathrm{NO}$ is an important regulator of resting $\mathrm{CBF}$; inhibition of NOS constricts cerebral arteries and decreases CBF [142-144].

Intraventricular administration of sodium nitroprusside, a NO donor, to patients with medically refractory vasospasm had variable effects on CBF and a high rate of adverse events [145]. Partial to complete reversal of angiographic vasospasm was seen in ten patients after sodium nitroprusside [146], and symptoms completely resolved in two. Vomiting was the most common adverse effect (in seven out of ten) and three patients had mild fluctuation in blood pressure. In three patients administered intrathecal sodium nitroprusside, clinical and angiographic improvement and excellent outcome with no systemic or neurological complications was reported [147].

Finally, transdermal nitroglycerin was tested in SAH. There were no differences in terms of DID and TCD velocities between the nitroglycerin group (nine patients) and the control group (eight patients). CBF, measured by perfusion computed tomography, was increased in the nitroglycerin group [148]. Large randomized and controlled trials of NO donors in $\mathrm{SAH}$ are in the planning stage.

\section{Endothelin-1 antagonists}

ET-1 was identified in 1988 [149]. It is a 21 amino acid peptide generated in the endothelium of blood vessels and has an important role in vascular tone regulation. ET-1 exerts its effects through two receptor subtypes, $\mathrm{ET}_{\mathrm{A}}$ and $E \mathrm{~T}_{\mathrm{B}}$. $\mathrm{ET}_{\mathrm{A}}$ receptors are found on vascular smooth muscle cells and mediate vasoconstriction of small and large blood vessels. $\mathrm{ET}_{\mathrm{B}}$ receptors, on the other hand, are found in brain, aorta, lung and kidney vascular endothelial cells where they modulate vasoconstriction in response to ET-1, through the production of vasodilator substances like prostacyclin and NO. They are also found on vascular smooth muscle cells where they can mediate vasoconstriction [150-153].

A phase lla trial of clazosentan (an $\mathrm{ET}_{\mathrm{A}}$ antagonist) demonstrated reduction in the incidence and severity of angiographic vasospasm [154]. Adverse events were comparable to placebo. An $\mathrm{ET}_{\mathrm{A} / \mathrm{B}}$ antagonist, TAK-044, was also tested in a phase II trial [155]. The drug was very well tolerated. Delayed ischemic deficits occurred in $29.5 \%$ of patients receiving active treatment and $36.6 \%$ of patients on placebo (risk reduction $0.8,95 \%$ confidence interval of 0.61 to 1.06$)$.

Most recently, clazosentan was tested in a controlled clinical trial enrolling 413 patients with SAH [156]. Moderate to severe angiographic spasm was significantly reduced, although there was no effect on outcome.

\section{Other therapies}

Enoxaparin, a low molecular weight heparin, was studied in a randomized clinical trial in $\mathrm{SAH}$ [157]. Although the incidence of DID and infarcts was reduced, the admission characteristics of the two groups were not well balanced.

Nicardipine prolonged-release implants $\left(\mathrm{NPRI}_{\mathrm{s}}\right)$ are placed in the subarachnoid space at the time of surgical clipping of aneurysm. Two case series describing the use of such implants are of interest [158,159]. In one, Kasuya and colleagues report an incidence of DID of $6 \%$ when they were applied in 69 patients with thick subarachnoid clots [158]. Recently, a randomized double-blind trial of the implants showed a dramatic reduction in incidence of angiographic vasospasm and infarctions [160].

A randomized, controlled trial compared dapsone to placebo $(n=49)$ in Fisher grade 3 and $4 \mathrm{SAH}$ [161]. It is thought to act as a glutamate receptor antagonist and reduced the incidence of DID (26.9\% versus $63.6 \%, p=0.01)$ and significantly improved outcome at discharge and three months (modified Rankin scale). 
This article is part of a review series on Stroke, edited by David Menon.

Other articles in the series can be found online at http://ccforum.com/articles/

theme-series.asp?series=CC_Stroke

\section{Conclusion}

There is a great need for new preventive strategies and therapies to lessen the impact of vasospasm following SAH. Unfortunately, to date the available literature provides few definitive answers. A number of factors conspire to make the task of better defining treatment exceedingly challenging. They include the complex, incompletely understood mechanisms operating in $\mathrm{SAH}$, the relatively low frequency of the disease, and most importantly, the large number of other factors that influence outcome is this population. To properly study interventions in $\mathrm{SAH}$, very large multi-center, prospective, tightly controlled studies are needed; unfortunately, their design and execution remains a major challenge.

This lack of definitive answers leads to a wide variation in the specifics of managing patients with SAH. Yet in general, current management focuses on screening patients at risk for DID, implementing multiple preventive measures and more aggressive interventions in selected patients. A number of neuroprotective approaches as well as the use of multimodal treatment regimens [162] are under active development and hold promise in the treatment of vasospasm.

\section{Competing interests}

SGK declares that he has no competing interests. MND consults for Novo Nordisk and Astellas Pharma.

\section{Additional data file}

\section{Additional file 1}

Major controlled trials of prevention and treatment of vasospasm following subarachnoid hemorrhage.

\section{References}

1. Ecker A, Riemenschneider PA: Arteriographic demonstration of spasm of the intracranial arteries. With special reference to saccular arteial aneurisms. J Neurosurg 1951, 8:660-667.

2. Robertson EG: Cerebral lesions due to intracranial aneurysms. Brain 1949, 72:150-185.

3. Millikan $\mathrm{CH}$ : Cerebral vasospasm and ruptured intracranial aneurysm. Arch Neurol 1975, 32:433-449.

4. Fisher CM, Roberson GH, Ojemann RG: Cerebral vasospasm with ruptured saccular aneurysm - the clinical manifestations. Neurosurgery 1977, 1:245-248.

5. Sarrafzadeh AS, Haux D, Ludemann L, Amthauer H, Plotkin M, Kuchler I, Unterberg AW: Cerebral ischemia in aneurysmal subarachnoid hemorrhage: a correlative microdialysis-PET study. Stroke 2004, 35:638-643.

6. Vajkoczy P, Horn P, Thome C, Munch E, Schmiedek P: Regional cerebral blood flow monitoring in the diagnosis of delayed ischemia following aneurysmal subarachnoid hemorrhage. J Neurosurg 2003, 98:1227-1234.

7. Allen GS, Ahn HS, Preziosi TJ, Battye R, Boone SC, Boone SC Chou SN, Kelly DL, Weir BK, Crabbe RA, et al.: Cerebral arterial spasm - a controlled trial of nimodipine in patients with sub- arachnoid hemorrhage. New Engl J Med 1983, 308:619-624.

8. Kassell NF, Torner JC, Haley EC Jr, Jane JA, Adams HP, Kongable GL: The International Cooperative Study on the Timing of Aneurysm Surgery. Part 1: Overall management results. J Neurosurg 1990, 73:18-36.

9. Kassell NF, Torner JC, Jane JA, Haley EC Jr, Adams HP: The International Cooperative Study on the Timing of Aneurysm Surgery. Part 2: Surgical results. J Neurosurg 1990, 73:37-47.

10. Petruk KC, West M, Mohr G, Weir BK, Benoit BG, Gentili F, Disney LB, Khan Ml, Grace M, Holness RO, et al.: Nimodipine treatment in poor-grade aneurysm patients. Results of a multicenter double-blind placebo-controlled trial. J Neurosurg 1988, 68:505-517.

11. Philippon J, Grob R, Dagreou F, Guggiari M, Rivierez M, Viars P: Prevention of vasospasm in subarachnoid haemorrhage. A controlled study with nimodipine. Acta Neurochirurgica 1986, 82:110-114.

12. Pickard JD, Murray GD, Illingworth R, Shaw MD, Teasdale GM, Foy PM, Humphrey PR, Lang DA, Nelson R, Richards $\mathrm{P}$, et al.: Effect of oral nimodipine on cerebral infarction and outcome after subarachnoid haemorrhage: British aneurysm nimodipine trial. BMJ 1989, 298:636-642.

13. Manno EM, Gress DR, Schwamm LH, Diringer MN, Ogilvy CS: Effects of induced hypertension on transcranial Doppler ultrasound velocities in patients after subarachnoid hemorrhage. Stroke 1998, 29:422-428.

14. Soehle M, Czosnyka M, Pickard JD, Kirkpatrick PJ: Continuous assessment of cerebral autoregulation in subarachnoid hemorrhage. Anesthesia Analgesia 2004, 98:1133-1139.

15. Solenski NJ, Haley EC Jr, Kassell NF, Kongable G, Germanson T, Truskowski L, Torner JC: Medical complications of aneurysmal subarachnoid hemorrhage: a report of the multicenter, cooperative aneurysm study. Participants of the Multicenter Cooperative Aneurysm Study. Crit Care Med 1995, 23:1007-1017.

16. Adams HP Jr, Kassell NF, Torner JC, Haley EC Jr: Predicting cerebral ischemia after aneurysmal subarachnoid hemorrhage: influences of clinical condition, CT results, and antifibrinolytic therapy. A report of the Cooperative Aneurysm Study. Neurology 1987, 37:1586-1591.

17. Wartenberg KE, Schmidt M, Fernandez A, Frontera JA, Claassen J, Ostapkovich ND, Badjatia N, Palestrant D, Parra A, Mayer SA: Multiterritorial symptomatic vasospasm after subarachnoid hemorrhage: predictors, associated complications, and impact on outcome. In International Stroke Conference: Feb 79, 2007; San Francisco. San Francisco, CA; 2007.

18. Ohman J, Servo A, Heiskanen O: Long-term effects of nimodipine on cerebral infarcts and outcome after aneurysmal subarachnoid hemorrhage and surgery. I Neurosurg 1991, 74: 8-13.

19. Smith RR, Clower BR, Grotendorst GM, Yabuno N, Cruse JM: Arterial wall changes in early human vasospasm. Neurosurgery 1985, 16:171-176.

20. Macdonald RL, Weir BK: A review of hemoglobin and the pathogenesis of cerebral vasospasm. Stroke 1991, 22:971982.

21. Borsody M, Burke A, Coplin W, Miller-Lotan R, Levy A: Haptoglobin and the development of cerebral artery vasospasm after subarachnoid hemorrhage. Neurology 2006, 66:634-640.

22. Suzuki H, Muramatsu M, Kojima T, Taki W: Intracranial heme metabolism and cerebral vasospasm after aneurysmal subarachnoid hemorrhage. Stroke 2003, 34:2796-2800.

23. Fuwa I, Mayberg M, Gadjusek C, Harada T, Luo Z: Enhanced secretion of endothelin by endothelial cells in response to hemoglobin. Neurologia Medico-chirurgica 1993, 33:739-743.

24. Misra HP, Fridovich I: The generation of superoxide radical during the autoxidation of hemoglobin. J Biol Chem 1972, 247:6960-6962.

25. Rubanyi GM: Endothelium-derived relaxing and contracting factors. J Cell Biochem 1991, 46:27-36.

26. Diringer $\mathrm{MN}$ : Subarachnoid hemorrhage: a multiple-organ system disease. Crit Care Med 2003, 31:1884-1885.

27. Yoshimoto $Y$, Tanaka $Y$, Hoya K: Acute systemic inflammatory response syndrome in subarachnoid hemorrhage. Stroke 2001, 32:1989-1993.

28. Hendryk S, Jarzab B, Josko J: Increase of the IL-1 beta and IL-6 levels in CSF in patients with vasospasm following aneurysmal SAH. Neuroendocrinol Lett 2004, 25:141-147. 
29. Mocco J, Ransom ER, Komotar RJ, Mack WJ, Sergot PB, Albert SM, Connolly ES Jr: Racial differences in cerebral vasospasm: a systematic review of the literature. Neurosurgery 2006, 58: 305-314.

30. Khurana VG, Sohni YR, Mangrum WI, McClelland RL, O'Kane DJ, Meyer FB, Meissner I: Endothelial nitric oxide synthase gene polymorphisms predict susceptibility to aneurysmal subarachnoid hemorrhage and cerebral vasospasm. J Cereb Blood Flow Metab 2004, 24:291-297.

31. Claassen J, Bernardini GL, Kreiter K, Bates J, Du YE, Copeland D, Connolly ES, Mayer SA: Effect of cisternal and ventricular blood on risk of delayed cerebral ischemia after subarachnoid hemorrhage: the Fisher scale revisited. Stroke 2001, 32:20122020.

32. Fisher CM, Kistler JP, Davis JM: Relation of cerebral vasospasm to subarachnoid hemorrhage visualized by computerized tomographic scanning. Neurosurgery 1980, 6:1-9.

33. Hijdra A, van Gijn J, Nagelkerke NJ, Vermeulen M, van Crevel H: Prediction of delayed cerebral ischemia, rebleeding, and outcome after aneurysmal subarachnoid hemorrhage. Stroke 1988, 19:1250-1256.

34. Qureshi Al, Sung GY, Suri MA, Straw RN, Guterman LR, Hopkins $\mathrm{LN}$ : Prognostic value and determinants of ultraearly angiographic vasospasm after aneurysmal subarachnoid hemorrhage. Neurosurgery 1999, 44:967-973; discussion 973-974.

35. de Oliveira JG, Beck J, Ulich C, Rathert J, Raabe A, Seifert V: Comparison between clipping and coiling on the incidence of cerebral vasospasm after aneurysmal subarachnoid hemorrhage: a systematic review and meta-analysis. Neurosurgical Rev 2007, 30:22-30; discussion 30-31.

36. Gruber A, Ungersbock K, Reinprecht A, Czech T, Gross C, Bednar M, Richling B: Evaluation of cerebral vasospasm after early surgical and endovascular treatment of ruptured intracranial aneurysms. Neurosurgery 1998, 42:258-267; discussion 267-268.

37. Macdonald RL, Rosengart A, Huo D, Karrison T: Factors associated with the development of vasospasm after planned surgical treatment of aneurysmal subarachnoid hemorrhage. J Neurosurg 2003, 99:644-652.

38. Qureshi Al, Sung GY, Razumovsky AY, Lane K, Straw RN, Ulatowski JA: Early identification of patients at risk for symptomatic vasospasm after aneurysmal subarachnoid hemorrhage. Crit Care Med 2000, 28:984-990.

39. Roos Y, Rinkel G, Vermeulen M, Algra A, van Gijn J: Antifibrinolytic therapy for aneurysmal subarachnoid hemorrhage: a major update of a cochrane review. Stroke 2003, 34:23082309.

40. Hop JW, Rinkel GJ, Algra A, van Gijn J: Initial loss of consciousness and risk of delayed cerebral ischemia after aneurysmal subarachnoid hemorrhage. Stroke 1999, 30:2268-2271.

41. Juvela S, Siironen J, Kuhmonen J: Hyperglycemia, excess weight, and history of hypertension as risk factors for poor outcome and cerebral infarction after aneurysmal subarachnoid hemorrhage. J Neurosurg 2005, 102:998-1003.

42. Lasner TM, Weil RJ, Riina HA, King JT Jr, Zager EL, Raps EC, Flamm ES: Cigarette smoking-induced increase in the risk of symptomatic vasospasm after aneurysmal subarachnoid hemorrhage. J Neurosurg 1997, 87:381-384.

43. Weir BK, Kongable GL, Kassell NF, Schultz JR, Truskowski LL, Sigrest A: Cigarette smoking as a cause of aneurysmal subarachnoid hemorrhage and risk for vasospasm: a report of the Cooperative Aneurysm Study. J Neurosurg 1998, 89:405411.

44. Doerksen K, Naimark BJ, Tate RB: Comparison of a standard neurological tool with a stroke scale for detecting symptomatic cerebral vasospasm. J Neurosci Nurs 2002, 34:320-325.

45. Newell DW, Grady MS, Eskridge JM, Winn HR: Distribution of angiographic vasospasm after subarachnoid hemorrhage: implications for diagnosis by transcranial Doppler ultrasonography. Neurosurgery 1990, 27:574-577.

46. Newell DW, Winn HR: Transcranial Doppler in cerebral vasospasm. Neurosurg Clinics North Am 1990, 1:319-328.

47. Jarus-Dziedzic K, Juniewicz H, Wronski J, Zub WL, Kasper E, Gowacki M, Mierzwa J: The relation between cerebral blood flow velocities as measured by TCD and the incidence of delayed ischemic deficits. A prospective study after subarachnoid hemorrhage. Neurological Res 2002, 24:582-592.
48. Lysakowski C, Walder B, Costanza MC, Tramer MR: Transcranial Doppler versus angiography in patients with vasospasm due to a ruptured cerebral aneurysm: A systematic review. Stroke 2001, 32:2292-2298

49. Suarez JI, Qureshi Al, Yahia AB, Parekh PD, Tamargo RJ, Williams MA, Ulatowski JA, Hanley DF, Razumovsky AY: Symptomatic vasospasm diagnosis after subarachnoid hemorrhage: evaluation of transcranial Doppler ultrasound and cerebral angiography as related to compromised vascular distribution. Crit Care Med 2002, 30:1348-1355.

50. Sviri GE, Britz GW, Lewis DH, Newell DW, Zaaroor M, Cohen W: Dynamic perfusion computed tomography in the diagnosis of cerebral vasospasm. Neurosurgery 2006, 59:319-325; discussion 324-325.

51. Sviri GE, Mesiwala AH, Lewis DH, Britz GW, Nemecek A, Newell DW, Lam A, Cohen W: Dynamic perfusion computerized tomography in cerebral vasospasm following aneurysmal subarachnoid hemorrhage: a comparison with technetium$99 \mathrm{~m}$-labeled ethyl cysteinate dimer-single-photon emission computerized tomography. J Neurosurg 2006, 104:404-410.

52. Yonas $\mathrm{H}$ : Cerebral blood measurements in vasospasm. Neurosurg Clinics North Am 1990, 1:307-318.

53. Yonas H, Sekhar L, Johnson DW, Gur D: Determination of irreversible ischemia by xenon-enhanced computed tomographic monitoring of cerebral blood flow in patients with symptomatic vasospasm. Neurosurgery 1989, 24:368-372.

54. Condette-Auliac S, Bracard S, Anxionnat R, Schmitt E, Lacour JC, Braun M, Meloneto J, Cordebar A, Yin L, Picard L: Vasospasm after subarachnoid hemorrhage: interest in diffusionweighted MR imaging. Stroke 2001, 32:1818-1824.

55. Phan TG, Huston J 3rd, Campeau NG, Wijdicks EF, Atkinson JL, Fulgham JR: Value of diffusion-weighted imaging in patients with a nonlocalizing examination and vasospasm from subarachnoid hemorrhage. Cerebrovasc Dis 2003, 15:177-181.

56. Jabre A, Babikian V, Powsner RA, Spatz EL: Role of single photon emission computed tomography and transcranial Doppler ultrasonography in clinical vasospasm. J Clin $\mathrm{Neu}-$ rosci 2002, 9:400-403.

57. Lad SP, Guzman R, Kelly ME, Li G, Lim M, Lovbald K, Steinberg GK: Cerebral perfusion imaging in vasospasm. Neurosurgical Focus 2006, 21:E7.

58. Unterberg AW, Sakowitz OW, Sarrafzadeh AS, Benndorf G, Lanksch WR: Role of bedside microdialysis in the diagnosis of cerebral vasospasm following aneurysmal subarachnoid hemorrhage. J Neurosurg 2001, 94:740-749.

59. Mee E, Dorrance D, Lowe D, Neil-Dwyer G: Controlled study of nimodipine in aneurysm patients treated early after subarachnoid hemorrhage. Neurosurgery 1988, 22:484-491.

60. Karinen $P$, Koivukangas $P$, Ohinmaa A, Koivukangas J, Ohman J: Cost-effectiveness analysis of nimodipine treatment after aneurysmal subarachnoid hemorrhage and surgery. Neurosurgery 1999, 45:780-784; discussion 784-785.

61. Rinkel GJ, Feigin VL, Algra A, van den Bergh WM, Vermeulen M, van Gijn J: Calcium antagonists for aneurysmal subarachnoid haemorrhage. Cochrane Database Systematic Rev 2005: CD000277.

62. Feigin VL, Rinkel GJ, Algra A, Vermeulen M, van Gijn J: Calcium antagonists in patients with aneurysmal subarachnoid hemorrhage: a systematic review. Neurology 1998, 50:876-883.

63. Abe K, Iwanaga $\mathrm{H}$, Inada $\mathrm{E}$ : Effect of nicardipine and diltiazem on internal carotid artery blood flow velocity and local cerebral blood flow during cerebral aneurysm surgery for subarachnoid hemorrhage. J Clin Anesth 1994, 6:99-105.

64. Haley EC Jr, Kassell NF, Torner JC: A randomized trial of nicardipine in subarachnoid hemorrhage: angiographic and transcranial Doppler ultrasound results. A report of the Cooperative Aneurysm Study. J Neurosurg 1993, 78:548553.

65. Haley EC Jr, Kassell NF, Torner JC: A randomized controlled trial of high-dose intravenous nicardipine in aneurysmal subarachnoid hemorrhage. A report of the Cooperative Aneurysm Study. J Neurosurg 1993, 78:537-547.

66. Papavasiliou AK, Harbaugh KS, Birkmeyer NJ, Feeney JM, Martin PB, Faccio C, Harbaugh RE: Clinical outcomes of aneurysmal subarachnoid hemorrhage patients treated with oral diltiazem and limited intensive care management. Surg Neurol 2001, 55:138-146; discussion 146-147. 
67. Saunders FW, Marshall WJ: Diltiazem: dose it affect vasospasm? Surg Neurol 1986, 26:155-158.

68. Shibuya M, Suzuki Y, Enomoto H, Okada T, Ogura K, Sugita K: Effects of prophylactic intrathecal administrations of nicardipine on vasospasm in patients with severe aneurysmal subarachnoid haemorrhage. Acta Neurochirurgica 1994, 131: 19-25.

69. Haley EC Jr, Kassell NF, Apperson-Hansen C, Maile MH, Alves WM: A randomized, double-blind, vehicle-controlled trial of tirilazad mesylate in patients with aneurysmal subarachnoid hemorrhage: a cooperative study in North America. J Neurosurg 1997, 86:467-474.

70. Kassell NF, Haley EC Jr, Apperson-Hansen C, Alves WM: Randomized, double-blind, vehicle-controlled trial of tirilazad mesylate in patients with aneurysmal subarachnoid hemorrhage: a cooperative study in Europe, Australia, and New Zealand. J Neurosurg 1996, 84:221-228.

71. Lanzino G, Kassell NF: Double-blind, randomized, vehicle-controlled study of high-dose tirilazad mesylate in women with aneurysmal subarachnoid hemorrhage. Part II. A cooperative study in North America. J Neurosurg 1999, 90:1018-1024.

72. Lanzino G, Kassell NF, Dorsch NW, Pasqualin A, Brandt L, Schmiedek P, Truskowski LL, Alves WM: Double-blind, randomized, vehicle-controlled study of high-dose tirilazad mesylate in women with aneurysmal subarachnoid hemorrhage. Part I. A cooperative study in Europe, Australia, New Zealand, and South Africa. J Neurosurg 1999, 90:1011-1017.

73. Haley EC Jr, Kassell NF, Alves WM, Weir BK, Hansen CA: Phase II trial of tirilazad in aneurysmal subarachnoid hemorrhage. A report of the Cooperative Aneurysm Study. J Neurosurg 1995, 82:786-790.

74. Kanamaru K, Weir BK, Findlay JM, Grace M, Macdonald RL: A dosage study of the effect of the 21-aminosteroid U74006F on chronic cerebral vasospasm in a primate model. Neurosurgery 1990, 27:29-38.

75. Steinke DE, Weir BK, Findlay JM, Tanabe T, Grace M, Krushelnycky BW: A trial of the 21-aminosteroid U74006F in a primate model of chronic cerebral vasospasm. Neurosurgery 1989, 24: 179-186.

76. Suzuki H, Kanamaru K, Kuroki M, Sun H, Waga S, Miyazawa T: Effects of tirilazad mesylate on vasospasm and phospholipid hydroperoxides in a primate model of subarachnoid hemorrhage. Stroke 1999, 30:450-455; discussion 455-456.

77. Egge A, Waterloo K, Sjoholm H, Solberg $T$, Ingebrigtsen $T$, Romner B: Prophylactic hyperdynamic postoperative fluid therapy after aneurysmal subarachnoid hemorrhage: a clinical, prospective, randomized, controlled study. Neurosurgery 2001, 49:593-605; discussion 605-606.

78. Lennihan L, Mayer SA, Fink ME, Beckford A, Paik MC, Zhang $H$, Wu YC, Klebanoff LM, Raps EC, Solomon RA: Effect of hypervolemic therapy on cerebral blood flow after subarachnoid hemorrhage: a randomized controlled trial. Stroke 2000, 31: 383-391.

79. Rinkel GJ, Feigin VL, Algra A, van Gijn J: Circulatory volume expansion therapy for aneurysmal subarachnoid haemorrhage. Cochrane Database Systematic Rev 2004:CD000483.

80. Suarez JI, Shannon L, Zaidat OO, Suri MF, Singh G, Lynch G, Selman WR: Effect of human albumin administration on clinical outcome and hospital cost in patients with subarachnoid hemorrhage. J Neurosurg 2004, 100:585-590.

81. Amin-Hanjani S, Ogilvy CS, Barker FG 2nd: Does intracisternal thrombolysis prevent vasospasm after aneurysmal subarachnoid hemorrhage? A meta-analysis. Neurosurgery 2004, 54: 326-334; discussion 334-335.

82. Sasaki T, Ohta T, Kikuchi H, Takakura K, Usui M, Ohnishi H, Kondo A, Tanabe $\mathrm{H}$, Nakamura J, Yamada $\mathrm{K}$, et al.: A phase II clinical trial of recombinant human tissue-type plasminogen activator against cerebral vasospasm after aneurysmal subarachnoid hemorrhage. Neurosurgery 1994, 35:597-604; discussion 604-605.

83. Zabramski JM, Spetzler RF, Lee KS, Papadopoulos SM, Bovill E, Zimmerman RS, Bederson JB: Phase I trial of tissue plasminogen activator for the prevention of vasospasm in patients with aneurysmal subarachnoid hemorrhage. J Neurosurg 1991, 75: 189-196.

84. Findlay JM, Kassell NF, Weir BK, Haley EC Jr, Kongable G, Germanson T, Truskowski L, Alves WM, Holness RO, Knuckey NW, et al.: A randomized trial of intraoperative, intracisternal tissue plasminogen activator for the prevention of vasospasm. Neurosurgery 1995, 37:168-176; discussion 177-178.

85. Kinouchi H, Ogasawara K, Shimizu H, Mizoi K, Yoshimoto T: Prevention of symptomatic vasospasm after aneurysmal subarachnoid hemorrhage by intraoperative cisternal fibrinolysis using tissue-type plasminogen activator combined with continuous cisternal drainage. Neurologia Medico-chirurgica 2004, 44:569-575; discussion 576-577.

86. Hamada J, Kai Y, Morioka M, Yano S, Mizuno T, Hirano T, Kazekawa K, Ushio Y: Effect on cerebral vasospasm of coil embolization followed by microcatheter intrathecal urokinase infusion into the cisterna magna: a prospective randomized study. Stroke 2003, 34:2549-2554.

87. Sasaki T, Kodama N, Kawakami M, Sato M, Asari J, Sakurai Y, Watanabe K, Onuma T, Matsuda T: Urokinase cisternal irrigation therapy for prevention of symptomatic vasospasm after aneurysmal subarachnoid hemorrhage: a study of urokinase concentration and the fibrinolytic system. Stroke 2000, 31: 1256-1262.

88. Klimo P Jr, Kestle JR, MacDonald JD, Schmidt RH: Marked reduction of cerebral vasospasm with lumbar drainage of cerebrospinal fluid after subarachnoid hemorrhage. J Neurosurg 2004, 100:215-224.

89. Muizelaar JP, Zwienenberg M, Rudisill NA, Hecht ST: The prophylactic use of transluminal balloon angioplasty in patients with Fisher Grade 3 subarachnoid hemorrhage: a pilot study. J Neurosurg 1999, 91:51-58.

90. Zwienenberg-Lee M, Hartmann J, Rudisill N, Muizelaar JP: The effect of prophylactic transluminal balloon angioplasty on cerebral vasospasm and outcome in patients with Fisher grade III subarachnoid hemorrhage. Results of a multi-center randomized clinical trial. In: International Stroke Conference: Feb 7-9, 2007; San Francisco. San Francisco, CA; 2007.

91. Hoh BL, Ogilvy CS: Endovascular treatment of cerebral vasospasm: transluminal balloon angioplasty, intra-arterial papaverine, and intra-arterial nicardipine. Neurosurg Clinics North Am 2005, 16:501-516, vi.

92. Jost SC, Diringer MN, Zazulia AR, Videen TO, Aiyagari V, Grubb $\mathrm{RL}$, Powers WJ: Effect of normal saline bolus on cerebral blood flow in regions with low baseline flow in patients with vasospasm following subarachnoid hemorrhage. J Neurosurg 2005, 103:25-30.

93. Aiyagari V, Cross DT 3rd, Deibert E, Dacey RG Jr, Diringer MN: Safety of hemodynamic augmentation in patients treated with Guglielmi detachable coils after acute aneurysmal subarachnoid hemorrhage. Stroke 2001, 32:1994-1997.

94. Miller JA, Dacey RG Jr, Diringer MN: Safety of hypertensive hypervolemic therapy with phenylephrine in the treatment of delayed ischemic deficits after subarachnoid hemorrhage. Stroke 1995, 26:2260-2266.

95. Mindea SA, Yang BP, Bendok BR, Miller JW, Batjer $\mathrm{HH}$ : Endovascular treatment strategies for cerebral vasospasm. Neurosurgical Focus 2006, 21:E13.

96. Brisman JL, Eskridge JM, Newell DW: Neurointerventional treatment of vasospasm. Neurological Res 2006, 28:769-776.

97. Coyne TJ, Montanera WJ, Macdonald RL, Wallace MC: Percutaneous transluminal angioplasty for cerebral vasospasm after subarachnoid hemorrhage. Canadian J Surg 1994, 37:391-396.

98. Murai Y, Kominami S, Kobayashi S, Mizunari T, Teramoto A: The long-term effects of transluminal balloon angioplasty for vasospasms after subarachnoid hemorrhage: analyses of cerebral blood flow and reactivity. Surg Neurol 2005, 64:122126; discussion 127.

99. Polin RS, Coenen VA, Hansen CA, Shin P, Baskaya MK, Nanda A, Kassell NF: Efficacy of transluminal angioplasty for the management of symptomatic cerebral vasospasm following aneurysmal subarachnoid hemorrhage. $J$ Neurosurg 2000, 92: 284-290.

100. Rosenwasser RH, Armonda RA, Thomas JE, Benitez RP, Gannon PM, Harrop J: Therapeutic modalities for the management of cerebral vasospasm: timing of endovascular options. Neurosurgery 1999, 44:975-979; discussion 979-980.

101. Rabinstein AA, Friedman JA, Nichols DA, Pichelmann MA, McClelland RL, Manno EM, Atkinson JL, Wijdicks EF: Predictors of outcome after endovascular treatment of cerebral vasospasm. Am J Neuroradiol 2004, 25:1778-1782. 
102. Yamamoto $Y$, Smith RR, Bernanke DH: Mechanism of action of balloon angioplasty in cerebral vasospasm. Neurosurgery 1992, 30:1-5; discussion 5-6.

103. Firlik KS, Kaufmann AM, Firlik AD, Jungreis CA, Yonas $\mathrm{H}$ : Intraarterial papaverine for the treatment of cerebral vasospasm following aneurysmal subarachnoid hemorrhage. Surg Neurol 1999, 51:66-74.

104. Kassell NF, Helm G, Simmons N, Phillips CD, Cail WS: Treatment of cerebral vasospasm with intra-arterial papaverine. $J$ Neurosurg 1992, 77:848-852.

105. Liu JK, Tenner MS, Gottfried ON, Stevens EA, Rosenow JM, Madan N, MacDonald JD, Kestle JR, Couldwell WT: Efficacy of multiple intraarterial papaverine infusions for improvement in cerebral circulation time in patients with recurrent cerebral vasospasm. J Neurosurg 2004, 100:414-421.

106. Milburn JM, Moran CJ, Cross DT 3rd, Diringer MN, Pilgram TK, Dacey RG Jr: Increase in diameters of vasospastic intracranial arteries by intraarterial papaverine administration. J Neurosurg 1998, 88:38-42.

107. Vajkoczy $P$, Horn $P$, Bauhuf $C$, Munch E, Hubner U, Ing D, Thome C, Poeckler-Schoeninger C, Roth H, Schmiedek P: Effect of intra-arterial papaverine on regional cerebral blood flow in hemodynamically relevant cerebral vasospasm. Stroke 2001, 32:498-505.

108. Polin RS, Hansen CA, German P, Chadduck JB, Kassell NF: Intra-arterially administered papaverine for the treatment of symptomatic cerebral vasospasm. Neurosurgery 1998, 42: 1256-1264; discussion 1264-1267.

109. McAuliffe W, Townsend M, Eskridge JM, Newell DW, Grady MS, Winn HR: Intracranial pressure changes induced during papaverine infusion for treatment of vasospasm. J Neurosurg 1995, 83:430-434.

110. Barr JD, Mathis JM, Horton JA: Transient severe brain stem depression during intraarterial papaverine infusion for cerebral vasospasm. Am J Neuroradiol 1994, 15:719-723.

111. Clyde BL, Firlik AD, Kaufmann AM, Spearman MP, Yonas $\mathrm{H}$ : Paradoxical aggravation of vasospasm with papaverine infusion following aneurysmal subarachnoid hemorrhage. Case report. J Neurosurg 1996, 84:690-695.

112. Tsurushima H, Kamezaki T, Nagatomo Y, Hyodo A, Nose T: Complications associated with intraarterial administration of papaverine for vasospasm following subarachnoid hemorrhage - two case reports. Neurologia Medico-chirurgica 2000, 40:112-115.

113. Smith WS, Dowd CF, Johnston SC, Ko NU, DeArmond SJ, Dillon WP, Setty D, Lawton MT, Young WL, Higashida RT, et al:: Neurotoxicity of intra-arterial papaverine preserved with chlorobutanol used for the treatment of cerebral vasospasm after aneurysmal subarachnoid hemorrhage. Stroke 2004, 35:25182522.

114. Carhuapoma JR, Qureshi Al, Tamargo RJ, Mathis JM, Hanley DF: Intra-arterial papaverine-induced seizures: case report and review of the literature. Surg Neurol 2001, 56:159-163.

115. Badjatia N, Topcuoglu MA, Pryor JC, Rabinov JD, Ogilvy CS, Carter BS, Rordorf GA: Preliminary experience with intra-arterial nicardipine as a treatment for cerebral vasospasm. $A m \mathrm{~J}$ Neuroradiol 2004, 25:819-826.

116. Feng L, Fitzsimmons BF, Young WL, Berman MF, Lin E, Aagaard $\mathrm{BD}$, Duong $\mathrm{H}$, Pile-Spellman J: Intraarterially administered verapamil as adjunct therapy for cerebral vasospasm: safety and 2-year experience. Am J Neuroradiol 2002, 23:1284-1290.

117. Biondi A, Ricciardi GK, Puybasset L, Abdennour L, Longo M, Chiras J, Van Effenterre R: Intra-arterial nimodipine for the treatment of symptomatic cerebral vasospasm after aneurysmal subarachnoid hemorrhage: preliminary results. $\mathrm{Am} \mathrm{J} \mathrm{Neu-}$ roradiol 2004, 25:1067-1076.

118. Hui C, Lau KP: Efficacy of intra-arterial nimodipine in the treatment of cerebral vasospasm complicating subarachnoid haemorrhage. Clin Radiol 2005, 60:1030-1036.

119. van den Bergh WM, Algra A, van der Sprenkel JW, Tulleken CA, Rinkel GJ: Hypomagnesemia after aneurysmal subarachnoid hemorrhage. Neurosurgery 2003, 52:276-281; discussion 281282.

120. Collignon FP, Friedman JA, Piepgras DG, Pichelmann MA, Mclver $\mathrm{Jl}$, Toussaint LG, 3rd, McClelland RL: Serum magnesium levels as related to symptomatic vasospasm and outcome following aneurysmal subarachnoid hemorrhage. Neurocritical Care 2004, 1:441-448.
121. Muir KW: Magnesium in stroke treatment. PostgradMed $J$ 2002, 78:641-645.

122. van den Bergh WM, Albrecht KW, Berkelbach van der Sprenkel JW, Rinkel GJ: Magnesium therapy after aneurysmal subarachnoid haemorrhage a dose-finding study for long term treatment. Acta Neurochirurgica 2003, 145:195-199; discussion 199.

123. Veyna RS, Seyfried D, Burke DG, Zimmerman C, Mlynarek M, Nichols V, Marrocco A, Thomas AJ, Mitsias PD, Malik GM: Magnesium sulfate therapy after aneurysmal subarachnoid hemorrhage. J Neurosurg 2002, 96:510-514.

124. Izumi Y, Roussel S, Pinard E, Seylaz J: Reduction of infarct volume by magnesium after middle cerebral artery occlusion in rats. J Cereb Blood Flow Metab 1991, 11:1025-1030.

125. Marinov MB, Harbaugh KS, Hoopes PJ, Pikus HJ, Harbaugh RE: Neuroprotective effects of preischemia intraarterial magnesium sulfate in reversible focal cerebral ischemia. $J$ Neurosurg 1996, 85:117-124.

126. Ram Z, Sadeh M, Shacked I, Sahar A, Hadani M: Magnesium sulfate reverses experimental delayed cerebral vasospasm after subarachnoid hemorrhage in rats. Stroke 1991, 22:922927.

127. van den Bergh WM, Zuur JK, Kamerling NA, van Asseldonk JT, Rinkel GJ, Tulleken CA, Nicolay K: Role of magnesium in the reduction of ischemic depolarization and lesion volume after experimental subarachnoid hemorrhage. J Neurosurg 2002, 97:416-422.

128. Boet $R$, Mee $E$ : Magnesium sulfate in the management of patients with Fisher Grade 3 subarachnoid hemorrhage: a pilot study. Neurosurgery 2000, 47:602-606; discussion 606607.

129. Wong GK, Chan MT, Boet R, Poon WS, Gin T: Intravenous magnesium sulfate after aneurysmal subarachnoid hemorrhage: a prospective randomized pilot study. J Neurosurg Anesthesiol 2006, 18:142-148.

130. Saver JL, Kidwell C, Eckstein M, Starkman S: Prehospital neuroprotective therapy for acute stroke: results of the Field Administration of Stroke Therapy-Magnesium (FAST-MAG) pilot trial. Stroke 2004, 35:e106-108.

131. Yahia AM, Kirmani JF, Qureshi Al, Guterman LR, Hopkins LN: The safety and feasibility of continuous intravenous magnesium sulfate for prevention of cerebral vasospasm in aneurysmal subarachnoid hemorrhage. Neurocritical Care 2005, 3:16-23.

132. van den Bergh WM, Algra A, van Kooten F, Dirven CM, van Gijn J, Vermeulen M, Rinkel GJ: Magnesium sulfate in aneurysmal subarachnoid hemorrhage: a randomized controlled trial. Stroke 2005, 36:1011-1015.

133. Schmid-Elsaesser R, Kunz M, Zausinger S, Prueckner S, Briegel J, Steiger $\mathrm{HJ}$ : Intravenous magnesium versus nimodipine in the treatment of patients with aneurysmal subarachnoid hemorrhage: a randomized study. Neurosurgery 2006, 58:1054-1065.

134. Prevedello DM, Cordeiro JG, de Morais AL, Saucedo NS Jr, Chen IB, Araujo JC: Magnesium sulfate: role as possible attenuating factor in vasospasm morbidity. Surg Neurol 2006, 65(Suppl 1): S1:14-1:20; discussion S1:20-1:21.

135. Brewer RP, Parra A, Lynch J, Chilukuri V, Borel CO: Cerebral blood flow velocity response to magnesium sulfate in patients after subarachnoid hemorrhage. J Neurosurg Anesthesiolesiol 2001, 13:202-206.

136. Amin-Hanjani S, Stagliano NE, Yamada M, Huang PL, Liao JK, Moskowitz MA: Mevastatin, an HMG-CoA reductase inhibitor, reduces stroke damage and upregulates endothelial nitric oxide synthase in mice. Stroke 2001, 32:980-986.

137. Laufs U, Fata VL, Liao JK: Inhibition of 3-hydroxy-3-methylglutaryl (HMG)-CoA reductase blocks hypoxia-mediated downregulation of endothelial nitric oxide synthase. $J \mathrm{Biol} \mathrm{Chem}$ 1997, 272:31725-31729.

138. Yamada M, Huang Z, Dalkara T, Endres M, Laufs U, Waeber C, Huang PL, Liao JK, Moskowitz MA: Endothelial nitric oxide synthase-dependent cerebral blood flow augmentation by L-arginine after chronic statin treatment. J Cereb Blood Flow Metab 2000, 20:709-717.

139. Tseng MY, Czosnyka M, Richards H, Pickard JD, Kirkpatrick PJ: Effects of acute treatment with pravastatin on cerebral vasospasm, autoregulation, and delayed ischemic deficits after aneurysmal subarachnoid hemorrhage: a phase II randomized placebo-controlled trial. Stroke 2005, 36:1627-1632. 
140. Lynch JR, Wang H, McGirt MJ, Floyd J, Friedman AH, Coon AL, Blessing R, Alexander MJ, Graffagnino C, Warner DS, et al.: Simvastatin reduces vasospasm after aneurysmal subarachnoid hemorrhage: results of a pilot randomized clinical trial. Stroke 2005, 36:2024-2026.

141. Palmer RM, Ferrige AG, Moncada S: Nitric oxide release accounts for the biological activity of endothelium-derived relaxing factor. Nature 1987, 327:524-526.

142. Faraci FM: Role of endothelium-derived relaxing factor in cerebral circulation: large arteries vs. microcirculation. $\mathrm{Am} J$ Physiol 1991, 261:H1038-1042.

143. Prado R, Watson BD, Kuluz J, Dietrich WD: Endotheliumderived nitric oxide synthase inhibition. Effects on cerebral blood flow, pial artery diameter, and vascular morphology in rats. Stroke 1992, 23:1118-1123; discussion 1124

144. You J, Johnson TD, Marrelli SP, Mombouli JV, Bryan RM Jr: P2u receptor-mediated release of endothelium-derived relaxing factor/nitric oxide and endothelium-derived hyperpolarizing factor from cerebrovascular endothelium in rats. Stroke 1999, 30:1125-1133.

145. Raabe A, Zimmermann M, Setzer M, Vatter H, Berkefeld J, Seifert $V$ : Effect of intraventricular sodium nitroprusside on cerebral hemodynamics and oxygenation in poor-grade aneurysm patients with severe, medically refractory vasospasm. Neurosurgery 2002, 50:1006-1013; discussion 1013-1014.

146. Kumar R, Pathak A, Mathuriya SN, Khandelwal N: Intraventricular sodium nitroprusside therapy: a future promise for refractory subarachnoid hemorrhage-induced vasospasm. Neurol India 2003, 51:197-202.

147. Thomas JE, Rosenwasser $\mathrm{RH}$ : Reversal of severe cerebral vasospasm in three patients after aneurysmal subarachnoid hemorrhage: initial observations regarding the use of intraventricular sodium nitroprusside in humans. Neurosurgery 1999, 44:48-57; discussion 57-58.

148. Reinert M, Wiest R, Barth L, Andres R, Ozdoba C, Seiler R: Transdermal nitroglycerin in patients with subarachnoid hemorrhage. Neurological Res 2004, 26:435-439.

149. Yanagisawa $M$, Kurihara $H$, Kimura $S$, Tomobe $Y$, Kobayashi $M$, Mitsui Y, Yazaki Y, Goto K, Masaki T: A novel potent vasoconstrictor peptide produced by vascular endothelial cells. Nature 1988, 332:411-415.

150. Davenport AP, Maguire JJ: Is endothelin-induced vasoconstriction mediated only by ETA receptors in humans? Trends Pharmacol Sci 1994, 15:9-11.

151. Hosoda K, Nakao K, Hiroshi A, Suga S, Ogawa Y, Mukoyama M, Shirakami G, Saito Y, Nakanishi S, Imura H: Cloning and expression of human endothelin-1 receptor cDNA. FEBS letters 1991, 287:23-26.

152. Molenaar P, O'Reilly G, Sharkey A, Kuc RE, Harding DP, Plumpton C, Gresham GA, Davenport AP: Characterization and localization of endothelin receptor subtypes in the human atrioventricular conducting system and myocardium. Circulation Res 1993, 72:526-538.

153. Ogawa Y, Nakao K, Arai H, Nakagawa O, Hosoda K, Suga S, Nakanishi S, Imura $\mathrm{H}$ : Molecular cloning of a non-isopeptideselective human endothelin receptor. Biochem Biophys Res Comm 1991, 178:248-255.

154. Vajkoczy P, Meyer B, Weidauer S, Raabe A, Thome C, Ringel F, Breu V, Schmiedek P: Clazosentan (AXV-034343), a selective endothelin A receptor antagonist, in the prevention of cerebral vasospasm following severe aneurysmal subarachnoid hemorrhage: results of a randomized, double-blind, placebo-controlled, multicenter phase Ila study. J Neurosurg 2005, 103: 9-17.

155. Shaw MD, Vermeulen M, Murray GD, Pickard JD, Bell BA, Teasdale GM: Efficacy and safety of the endothelin, receptor antagonist TAK-044 in treating subarachnoid hemorrhage: a report by the Steering Committee on behalf of the UK/ Netherlands/Eire TAK-044 Subarachnoid Haemorrhage Study Group. J Neurosurg 2000, 93:992-997.

156. Macdonald RL, Kassell N, Mayer S, Schmiedek P, Weidauer S, Pasqualin A: Randomized trial of Clazosentan for prevention of vasospasm after aneurysmal subarachnoid hemorrhage. In: International Stroke Conference: Feb 7-9, 2007; San Francisco. San Francisco, CA; 2007.

157. Wurm G, Tomancok B, Nussbaumer K, Adelwohrer C, Holl K: Reduction of ischemic sequelae following spontaneous sub- arachnoid hemorrhage: a double-blind, randomized comparison of enoxaparin versus placebo. Clin Neurol Neurosurg 2004, 106:97-103.

158. Kasuya H, Onda H, Sasahara A, Takeshita M, Hori T: Application of nicardipine prolonged-release implants: analysis of $97 \mathrm{con}$ secutive patients with acute subarachnoid hemorrhage. Neurosurgery 2005, 56:895-902.

159. Kasuya H, Onda H, Takeshita M, Okada Y, Hori T: Efficacy and safety of nicardipine prolonged-release implants for preventing vasospasm in humans. Stroke 2002, 33:1011-1015.

160. Barth M, Capelle HH, Weidauer S, Weiss C, Munch E, Thome C Luecke T, Schmiedek P, Kasuya H, Vajkoczy P: Effect of nicardipine prolonged-release implants on cerebral vasospasm and clinical outcome after severe aneurysmal subarachnoid hemorrhage: a prospective, randomized, double-blind phase Ila study. Stroke 2007, 38:330-336.

161. Garcia-Pastor C, Rios C, Nathal E: Neuroprotector effect of Dapsone in patients with subarachnoid hemorrhage: A controlled study. In: International Stroke Conference: Feb 7-9, 2007: San Francisco. San Francisco, CA: 2007.

162. Keller E, Krayenbuhl N, Bjeljac M, Yonekawa Y: Cerebral vasospasm: results of a structured multimodal treatment. Acta Neurochir Supp/ 2005, 94:65-73. 